\title{
KONFLIK PEMEKARAN WILAYAH DI NANGGROE ACEH DARUSSALAM (NAD) PASCA PERJANJIAN HELSINKI
}

\author{
M. Sahlan Hanafi, dkk. \\ IAIN Ar-Raniry Aceh \\ e-mail: sahlan_hanafiah@yahoo.com
}

\begin{abstract}
The purposes of this research are to describe the processes of the emerge of ideas to establish the province of ABAS and explain the factors supporting the idea and to explain the reasons of NAD government to reject the expand of ABAS province. Applying qualitative methods using field observation and media discourse study. It was found that media discourse and the proposal for province expand of ABAS rose pro and contra in all level of society that impacted in horizontal and vertical conflict.

Tujuan penelitian ini adalah untuk mendeskripsikan proses munculnya ide pembentukan Provinsi ABAS dan menjelaskan faktor-faktor yang mendorong munculnya ide tersebut serta menjelaskan mengapa Pemerintah pusat NAD tidak menyetujui pemekaran Provinsi ABAS. Metode penelitian yang digunakan dalam penelitian ini adalah metode penelitian kualitatif. Tekhnik pengumpulan data yang digunakan adalah observasi di lapangan dan mengamati perkembangan wacana pemekaran melalui media. Ditemukan bahwa wacana dan usulan pemekaran Provinsi ABAS dari Provinsi NAD telah menimbulkan pro dan kontra di berbagai lapisan masyarakat sehingga memunculkan konflik horizontal dan vertikal.
\end{abstract}

Keywords: pemekaran wilayah, konflik horizontal, konflik vertikal 


\section{A. Pendahuluan}

Iklim reformasi di Indonesia membuka peluang untuk terjadinya perubahan di setiap sektor kehidupan pemerintahan. Sistem pemerintahan pusat Negara Republik Indonesia yang cenderung sangat sentralistik pada masa pemerintahan Orde Baru diubah dengan sistem pemerintahan otonomi daerah yang desentralistik. Pelaksanaan otonomi daerah yang digagas sejak awal tahun 2001 telah membawa perubahan kebijakan politik di tingkat daerah (lokal). Lahimya Undang-Undang Otonomi Daerah dijadikan payung hukum bagi setiap daerah untuk memiliki hak dan kewajiban serta wewenang dalam mengatur dan mengurus sendiri urusan pemerintahan dan kepentingan daerahnya. ${ }^{1}$

Di samping itu keberadaan UU Otonomi Daerah telah mengilhami bagi daerah-daerah di wilayah Indonesia untuk melakukan pemekaran wilayahnya. Ide pemekaran wilayah ini tidak hanya muncul dari level bawah yaitu dari beberapa kecamatan menjadi kabupaten/kota tetapi ide ini juga muncul pada level atas yaitu dari beberapa kabupaten/kota menjadi sebuah provinsi baru.

Fenomena munculnya ide pemekaran wilayah yang terjadi pada hampir seluruh wilayah provinsi di Indonesia sudah tidak dapat dibendung lagi. Beberapa kecamatan dalam suatu daerah berubah menjadi sebuah kabupaten/kota yang memisahkan diri dari kabupaten/kota induknya ${ }^{2}$ dan ada pula beberapa kabupaten/kota bergabung membentuk satu provinsi baru. ${ }^{3}$ Gejala-gejala munculnya ide pemekaran tersebut ada yang berhasil diwujudkan namun ada juga yang masih mengalami hambatan dalam merealisasikan ide pemekaran daerah mereka. ${ }^{4}$

Ide pemekaran wilayah dari beberapa kabupaten/kota bergabung menjadi satu provinsi juga muncul di provinsi Nanggroe Aceh Darussalam. Pada saat sekarang ini, di wilayah Aceh telah muncul upaya untuk membentuk

\footnotetext{
1 Undang-Undang Republik Indonesia Nornor 32 Tahun 2004.

2 Sebagaimana yang terjadi pada wilayah Aceh Barat. Pada masa sekarang ini kabupaten Aceh Barat telah mengalami pemekaran menjadi 4 kabupaten yaitu Aceh Jaya, Aceh Barat, Nagan Raya dan Siemeulu.

${ }^{3}$ Sebagaimana yang terjadi di Provinsi Maluku, Riau, dan Papua.

4 Salah satu pernekaran dari Kabupaten Ikota yang masih mengalami hambatan adalah Provinsi ALA dan ABAS.
} 
provinsi baru yaitu Provinsi Aceh Tenggara dan Gayo Lues (ALA) dan Aceh Barat Selatan (ABAS). Serangkaian usaha telah dan sedang ditempuh untuk mewujudkan lahimya dua buah provinsi baru dari induknya Nanggroe Aceh Darussalam. Sikap pro dan kontra atas ide inipun menjadi berita hangat pada media massa lokal. Serangkaian, tekanan dan juga janji digelar melalui unjuk rasa dan demonstrasi demi disahkannya pemekaran di daerah mereka. ${ }^{5} \mathrm{Be}-$ ragam pendapat dan komentar diajukan tokoh-tokoh yang berada di belakang ide tersebut agar segera terealisasinya provinsi baru tersebut. Akan tetapi ada juga sebagian tokoh dan pakar yang tidak sependapat dengan ide pemekaran wilayah tersebut. ${ }^{6}$

Di tengah hangatnya ide pembentukan Provinsi ALA dan ABAS sebenarnya ada point khusus dalam Memorandum of Understanding (MoU) Helsinki ${ }^{7}$ yang perlu dicermati oleh para tokoh-tokoh penggagas ide tersebut. Dalam MoU Helsinki telah disebutkan bahwa wilayah Aceh yang dimaksud adalah wilayah Aceh yang disetujui oleh Negara Kesatuan Republik Indonesia pada tahun 1956. Kondisi ini telah menimbulkan konflik di Aceh, baik itu konflik horizontal maupun konflik vertikal di tengah semangat ingin melaksanakan MoU Helsinki dan keinginan untuk memekarkan provinsi NAD. Oleh karena itu penelitian ini mencoba mengekplorasi bagaimana ide pemekaran wilayah NAD khususnya di Aceh Barat Selatan (ABAS) bisa muncul pasca perdamaian?

\section{B. Konflik dan Analisis Konflik}

Konflik berasal dari bahasa Latin, confligere yang berarti benturan. Dalam kamus the Collins Consice sebagaimana yang dikutip oleh Gunaryo menjelaskan bahwa konflik adalah "a struggle between opposing forces". Se-

5 Lihat beberapa berita hangat yang dimuat oleh media massa local seputar isu-isu pernekaran wilayah di wilayah ALA dan ABAS pada harian Serambi dan tabloid Kontras yang terbit sekitar bulan Mei 2008.

6 Gubernur Aceh mengeluarkan surat edaran yang ditujukan kepada bupati untuk tidak memberi peluang adanya demo-demo yang mem-pressure erdirinya provinsi ALA dan ABAS.

${ }^{7}$ MoU Helsinki adalah perjanjian antara Pemerintah Republik Indonesia dan Gerakan Aceh Merdeka (GAM) yang dilakukan di Helsinki salah satu wilayah di Erofa perjanjian ini mengikat kedua belah pihak untuk mengakhiri konflik yang telah berlangsung cukup panjang di Aceh. Perjanjian ini di prakarsai oleh Martti Ahtisaari mantan presiden Finlandia, sebagai ketua dewan direktur Crisis Management Initiative (CMI), fasilitator proses negoisasi dan kerja ini didukung oleh Negara-negara Uni Eropa. 
lain itu konflik juga diartikan sebagai "opposition between ideas, and/or interests". Dengan demikian menurut kamus tersebut konflik dapat berbentuk fisik dan bisa pula berbentuk wacana. ${ }^{8}$

Secara konseptual, konflik dibedakan dengan kekerasan. Konflik (conflict) adalah hubungan antara dua pihak atau lebih (individu atau kelompok) yang memiliki, atau mereka menganggap memiliki tujuan yang bertentangan. Sedangkan kekerasan (violence) meliputi tindakan, kata-kata dan sikap struktur atau system yang menyebabkan kerusakan fisik, psikis dan lingkungan, dan/atau menutup kemungkinan orang untuk mengembangkan potensinya. ${ }^{9}$

Ada empat (4) tipe konflik yang berdasarkan hubungan antara tujuan dan tingkah laku.10 Adapun keempat tipe konflik tersebut adalah sebagai berikut:

1. Kondisi Tanpa Konflik (No Conflict). Kondisi ini merupakan kondisi yang diinginkan oleh setiap masyarakat. Namun demikian kelompok atau masyarakat yang ingin damai itu tetap bertahan lama maka mereka harus bisa hidup dinamis dengan cant mengatasi konf1ik secara kreatif.

2. Konflik Laten (Latent Conflict). Konflik laten adalah konflik yang berada di bawah permukaan. Untuk dapat menyelesaikan konflik tipe ini maka konflik tersebut harus dibawa ke permukaan terlebih dahulu sebelum dapat diselesaikan secara efektif.

3 Konflik terbuka (Open Conflict). Konflik ini mengakar secara dalam serta sangat tampak jelas, dan memerlukan tindakan untuk mengatasi penyebab yang mengakar serta efek yang tampak.

4. Konflik Permukaan (Surface Conflict). Konflik ini memiliki akar yang tidak dalam atau tidak mengakar. Konflik permukaan ini kemungkinan muncul karena kesalahanpemahaman mengenai sasaran dan dapat diatasi dengan perbaikan komunikasi.

${ }^{8}$ Achmad Gunaryo, "Konflik dan Pendekatan terhadapnya", dalam buku M. Mukhsin Jamil, (ed.), Mengelola Konflik Membangun Damai, (Semarang: WMC IAIN Walisongo, 2007), h. 31.

${ }^{9}$ Sholihan, "Memahami Konflik," dalam M. Mukhsin Jamil, (ed.), Mengelola Konflik Membangun Damai, h. 6.

${ }^{10}$ Sholihan, “Memahami Konflik,” h. 10. 


\section{Teori-teori Penyebab Konflik}

Suatu konflik dapat terjadi karena disebabkan oleh beberapa faktor. Untuk mengetahui faktor-faktor penyebab timbulnya konflik dalam suatu masyarakat maka perlu diketahui terlebih dahulu teori-teori besar tentang penyebab konflik. ${ }^{11}$ Adapun teori-teori besar tersebut adalah sebagai berikut:

1. Teori Hubungan Komunitas (Community Relations Theory). Teori ini mengasumsikan bahwa konflik disebabkan oleh polarisasi, ketidakpercayaan, dan permusuhan antara kelorupok-kelompok yang berbeda dalam suatu komunitas.

2. Teori Negosiasi Utama (Principled Negosiation Theory). Teori ini mengasumsikan bahwa konflik itu disebabkan oleh posisi yang tidak tepat serta pandangan tentang 'zero-sum' mengenai konflik yang diadopsi oleh kelompok yang bertentangan.

3. Teori Kebutuhan Manusia (Human Needs Theory). Teori ini mengasumsikan bahwa konflik yang berakar dalam disebabkan oleh kebutuhan dasar manusia baik itu fisik, psikis, maupun sosial yang tidak terpenuhi atau dikecewakan.

4. Teori ldentitas (Identity Theory). Teori ini mengasumsikan bahwa konflik itu timbul disebabkan oleh perasaan akan adanya identitas yang terancam.

5. Teori Miskomunikasi Antar Budaya (Intercultural Miscommunication Theory). Teori ini mengasumsikan bahwa konflik itu disebabkan oleh pertentangan antar gaya komunikasi antar budaya yang berbeda.

6. Teori Transformasi Konflik (Conflict Transformation Theory). Teori ini mengasumsikan bahwa konflik disebabkan oleh persoalan nyata berupa ketidaksetaraan dan ketidakadilan yang ditunjukkan oleh kerangka kerja sosial, budaya dan ekonomi yang saling bersaingan.

\section{Pendekatan terhadap Konflik}

Pendekatan di sini tidak hanya digunakan untuk memahami onflik tetapi juga dapat digunakan untuk menyelesaikan konflik, ususnya konflik yang berpotensi membawa kerusakan bagi ehidupan manusia, seperti konflik ke-

11 Ibid., h. 16-18. 
kerasan (violent conflict). Menurut Gunaryo ${ }^{12}$ ada enam pendekatan yang biasa dipakai untuk menganalisis konflik. Adapun keenam pendekatan tersebut adalah sebagai berikut:

1. Pendekatan Ketahanan Sosial (Social Resilience). Seringkali konflik terjadi akibat dari adanya isu-isu yang tidak (belum tentu) dapat dipertanggungjawabkan kebenarannya. Karena itu perlu dilakukan upayaupaya untuk menyadarkan masyarakat melalui proses-proses pembelajaran maupun pemberdayaan. Penguatan civil society merupakan kunci dalam pendekatan ini. Dengan pendekatan ini diasumsikan bahwa dalam masyarakat ada kemampuan intemal untuk mengatasi (potensi) konflik maupun perselisihan.

2. Pendekatan Kesejahteraan (Social Prosperity). Asumsi dasar dari pendekatan ini menyatakan bahwa konflik itu terjadi akibat dari adanya kemiskinan. Kemiskinan ini selanjutnya memicu sejumlah (potensi) kerawanan sosial. Oleh karena itu, kesejahteraan yang baik diasumsikan dapat mengeliminir konflik. Bentuk pendekatan kesejahteraan ini banyak. Diantaranya adalah penyediaan lapangan pekerjaan dan gaji yang mencukupi.

3. Pendekatan Keamanan (Security). Pendekatan keamanan mengindikasikan adanya tindakan-tindakan represif terhadap segala bentuk konflik. Dengan pendekatan keamanan, Negara diasumsikan memiliki hak untuk melakukan apa saja untuk tidak hanya mencegah tetapi juga untuk meredam konflik. Kondisi ini dicapai dengan melibatkan alat-alat keamanan Negara.

4. Pendekatan Asimilatif. Pendekatan asimilasi bertujuan untuk mengaburkan identitas lama dan sebaliknya membentuk identitas bam. Konflik yang terjadi sering kali dipicu oleh perbedaan-perbedaan identitas, baik itu etnik maupun agama. Perkawinan sering dipercaya sebagai bentuk asimilasi yang terbaik. Dengan perkawinan maka akan terjadi pencampuran identitas, khususnya generasi berikutnya. Misalnya, seseorang yang dilahirkan dari seorang ibu yang berasal dari etnik Cina dan seorang bapak yang beretnik Jawa akan kesulitan mengidentifikasi dirinya sendiri berasal dari lawan atau Cina. Identitas lama menjadi kabur dan bahkan hilang membentuk identitas yang sama sekali baru.

${ }^{12}$ Achmad Gunaryo, "Konflik dan Pendekatan Terhadapnya, " h. 39-42. 
5. Pendekatan Pembagian Kekuasaan (Power Sharing). Konflik politik biasanya dapat terpecahkan dengan melakukan pembagian kekuasaan pada mereka yang terlibat dalam konflik. Politik pada saat sekarang ini sering dipahami dengan kekuasaan. Pembagian kekuasaan sering menjadi jalan keluar untuk mengakhiri konflik di masyarakat. Dengan pembagian ini maka rasa diperintah oleh kelompok tertentu akan terkurangi.

6. Pendekatan Hukum. Seringkali konflik muncul akibat dari lemahnya penegakan hukum. Hukum yang diasumsikan dapat menyelesaikan persoalan, justru menimbulkan persoalan ketidakadilan. Hukum juga pada kenyataannya sering memihak, dan sebaliknya tidak memberikan keadilan bagi semua, terutama yang miskin. Hukum hanya untuk mereka yang bisa membeli. Suatu hal yang wajar apabila lebih banyak orang miskin yang mendekam di penjara ketimbang orang kaya. Penegakan hukum yang adil dan tidak memihak dipercaya akan dapat mencegah konflik atau mengakhiri konflik. Selama hukum tidak bisa memberikan rasa adil, maka konflik akan terus bermunculan.

Berbagai pendekatan di atas tentu memiliki kelemahannya masingmasing. Tidak semua konflik dapat dimengerti dan dianalisis dengan semua pendekatan di atas. Dengan demikian kondisi ini mengindikasikan bahwa konflik itu selalu bersifat dinamis. Watak dasar konflik akan selalu berubahubah. Karena bisa jadi konflik itu terjadi akibat perbedaan pandangan tentang hal yang sama.

\section{E. Analisis dan Pemetaan Konflik}

Analisis konflik adalah proses praktis untuk menguji dan memahami realitas konflik dari perspektif yang beragam kemudian menjadi dasar pijakan dalam pengembangan strategi dan perencanaan aksi. ${ }^{13}$ Dalam konteks ini, setiap orang yang bekerja dan aktif dalam penanganan konflik haruslah berusaha untuk memperoleh pemahaman yang lebih baik mengenai dinamika, hubungan dan isu-isu terkait dengan situasi (konflik) yang bisa membantu mereka untuk merencanakan strategi dan melakukan tindakan yang lebih baik. Keberhasilan pada langkah ini akan merupakan entry point untuk men-

13 Tolkhah, "Pemetaan Konflik (Conflict Mapping)," dalam M. Mukhsin Jamil, (ed.), Mengelola Konflik Membangun Damai, h. 49. 
capai kesuksesan pada langkah selanjutnya, yakni penyusunan strategi dan pelaksanaan tindakan penanganan konflik secara tepat. Sebaliknya, kegagalan pada langkah ini akan berakibat pada kegagalan pada langkah selanjutnya. Akibatnya bisa fatal, konflik itu bukannya tertangani tetapi justru makin membesar.

Ada lima kegunaan dan manfaat analisis konflik, ${ }^{14}$ yaitu:

1. Analisis konflik akan memberikan pemahaman latar belakang dan sejarah situasi konflik serta peristiwa (konflik) terkini.

2. Analisis konflik berguna untuk mengidentifikasi semua kelompok atau pihak relevan yang terlibat dalam konflik, tidak hanya pihak yang utama atau yang jelas-jelas terlibat dalam konflik. Semakin banyak pihak (baik individu maupun kelompok) yang terlibat secara langsung ataupun tidak langsung dalam suatu konflik maka akan semakin kompleks suatu konflik itu ditangani.

3. Analisis konflik juga penting untuk memberikan pemahaman perspektif dari semua kelompok atau pihak tersebut untuk mengetahui lebih luas tentang bagaimana relasi mereka satu sama lain.

4. Analisis konflik berfungsi juga untuk mengidentifikasi faktor-faktor dan trend-trend yang menopang konflik itu berguna untuk belajar dari kegagalan dan juga kesuksesan.

Sedangkan pemetaan konflik merupakan salah satu teknik dari sekian banyak teknik atau alat dalam menganalisa dan memecahkan konflik. Melalui pemetaan konflik akan dapat diketahui secara lebih udah dan akurat hal-hal sebagai berikut:

1. Identitas para pihak yang terlibat baik secara langsung maupun tidak langsung dalam konflik.

2. Jenis relasi para pihak yang terlibat dalam konflik.

3. Berbagai kepentingan yang terlibat dalam konflik.

4. Berbagai isu yang terlibat dalam konflik.

5. Pihak yang dapat didorong dalam melakukan resolusi konflik.

Pemetaan adalah suatu teknik yang dipakai untuk merepresentasikan konflik dalam bentuk gambar (grafis) dengan menempatkan para pihak yang

${ }^{14}$ Ibid, h. 50-52. 
terlibat dalam konf1ik baik dalam hubungannya" dengan masalah maupun antar para pihak sendiri. Melalui teknik ini, konflik yang sudah dinarasikan tetapi masih sangat abstrak gambarannya akan dapat dengan mudah untuk diketahui dan dibaca.

\section{F. Wacana Ide Pembentukan Provinsi ABAS}

Pergolakan seputar diskursus tentang pemekaran wilayah sudah mengkristal dan mewacana dengan cepat di kalangan masyarakat Indonesia. Isu ini bagaikan bola salju yang terus menggelinding dalam zona politik lokal. Harus diakui bahwa diskursus tersebut sesungguhnya muncul tidak terlepas dari keinginan kuat masyarakat dan elit politik untuk mengadakan perubahan dalam usaha untuk mensejahterakan kehidupan mereka.

Wacana mengenai pemekaran provinsi baru di Aceh telah lama imbul sebelum terjadinya musibah tsunami yang telah meluluhlantakkan sebagian daerah pesisir Aceh dan terjadinya perjanjian damai antara pemerintah pusat Republik Indonesia dengan Gerakan Aceh Merdeka (GAM) di Helsinki yang dimediasi oleh mantan Presiden Finlandia. Pada awalnya wacana tersebut digulirkan masyarakat yang tinggal disekitar Taman Nasional Leuser pada tahun 1999. Mereka berkeinginan untuk membentuk provinsi sendiridisebut dengan provinsi ALA (Aceh Leuser Antara). Dalam hal bupaten yang berkeinginan untuk membentuk provinsi tersebut Aceh Tengah, Aceh Tenggara, Aceh Singkil, Kota Lussalam, Gayo Lues dan Bener Meriah.

Meskipun wacana tentang pembentukan Provinsi ALA ini mengalami tantangan yang besar dari elit politik pemerintah Aceh akan tetapi wacana ini juga mengilhami dan mendorong kabupaten lain yang berada di daerah pesisir pantai barat Aceh untuk membentuk provinsi baru. Pada tahun 2003 program pemekaran provinsi Aceh Barat Selatan (ABAS) mulai digulirkan. Kabupaten atau kota yang akan bergabung dalam provinsi ini adalah Aceh Selatan, Aceh Barat, Aceh Barat Daya, Nagan Raya dan Simeulue.

Wacana pemekaran provinsi ini begitu menggebu menyusul berhasilnya pemekaran beberapa provinsi di Indonesia. Di antaranya pembentukan provinsi Banten sebagai hasil pemekaran dari Jawa Barat, Bangka-Belitung dari Sumatera Selatan, Maluku Utara dari Maluku, Kepulauan Riau dari Riau dan sebagainya. Dalam UU 22/1999 dan PP 129/2000 tentang Persyaratan, Pembentukan dan Kriteria Pemekaran, Penghapusan dan Penggabungan Daerah 
dijelaskan bahwa ada sejumlah syarat harus terpenuhi dalam pemekaran suatu daerah. Adapun syarat-syarat tersebut diantaranya adalah kemampuan ekonomi, potensi daerah, sosial budaya, jumlah penduduk, luas daerah dan pertimbangan lain yang memungkinkan terselenggaranya otonomi daerah.

Sesuai dengan aturan tersebut, ada beberapa prosedur yang arus dilakukan dalam mengusulkan pemekaran provinsi baru, yaitu:

1. Ada kemauan politik dari pemerintah daerah dan masyarakat yang bersangkutan.

2. Pengusulan pemekaran provinsi harus didukung oleh penelitian awal yang dilakukan secara objektif.

3. Usulan pemekaran disampaikan kepada pemerintah pusat dengan lampiran hasil penelitian, persetujuan DPRD Provinsi yang dalam hal ini DPRA (Dewan Perwakilan Rakyat Aceh) dan DPRK (Dewan Perwakilan Rakyat Kabupaten/Kota) bersangkutan serta dituangkan dalam bentuk Surat Keputusan.

4. Berdasarkan usulan Gubernur, Menteri Dalam Negeri akan memproses lebih lanjut dengan menugaskan tim.

5. Setelah Menteri Dalam Negeri mengeluarkan rekomendasi maka proses selanjutnya akan dilakukan oleh Presiden dan DPR-RI, hingga kemudian keluar undang-undangnya.

\section{Faktor yang Mendorong Pembentukan Provinsi ABAS}

Adapun faktor utama yang mendorong timbulnya ide pemekaran Provinsi ABAS dari provinsi induk adalah untuk percepatan pembangunan di segala bidang karena selama ini daerah Aceh Barat dan Aceh Selatan merupakan daerah yang mengalami keterlambatan pembangunan (modernisasi) baik itu pembangunan infrastruktur ataupun yang non-infrastruktur. Kondisi tersebut merupakan dampak yang terjadi dari model pemerintahan yang bersifat sentralistik. Suatu daerah yang jauh jaraknya dengan pusat pemerintahan telah membuat daerah tersebut terisolasi dan luput dari perhatian pemerintah. Pada akhimya dapat dipastikan daerah tersebut mengalami ketertinggalan di berbagai bidang.

Sebagaimana yang dikemukakan oleh Sekretaris Komisi D DPRK Aceh Selatan, Baidarus Isa, kepada harian Analisa bahwa daerah Aceh sangat luas, sehingga diperlukan "pemangkasan" rentang kendali untuk mencapai efekti- 
vitas pemerataan pembangunan. Fakta menunjukkan bahwa yang terjadi selama ini adalah beberapa daerah yang letaknya berjauhan dari pusat kendali pemerintahan provinsi jauh tertinggal di berbagai aspek dibandingkan dengan daerah yang lebih dekat. Kondisi ini menggambarkan adanya kesenjangan atau ketimpangan dan ketidakadilan pembangunan selama ini. ${ }^{15}$

Baidarus memberi contoh, salah satu kabupaten yang tertinggal pembangunannya adalah Aceh Selatan. Kondisi kertinggalan itu tampak jelas pada prasarana sektor perhubungan darat adalah salah satu contoh yang tidak bisa disembunyikan. Selama puluhan tahun kondisi buruk ruas jalan satu-satunya yang menghubungkan daerah pesisir barat Aceh dengan Sumatera Utara tidak pernah dibenahi secara serius oleh pemerintah provinsi kecuali perbaikan yang sifatnya tambal sulam. Beliau menambahkan pula bahwa perbaikan ruas jalan yang membentang di tiga gunung dekat Tapak Tuan dari masa ke masa hanya dalam bentuk "memoles" permukaan jalan tanpa menyentuh konstruksi dasar jalan itu sendiri sehingga kerusakan akan terus menerus terjadi sepanjang tahun. Keadaan ini telah menyebabkan hubungan antara daerah yang satu ke daerah yang lain sering terganggu. Di samping itu tingginya ketergantungan masyarakat Aceh dengan Sumatera Utara, baik sebagai pasar penjualan hasil kekayaan alam Aceh maupun sebagai daerah pemasok berbagai kebutuhan pokok untuk kabupaten-kabupaten di sepanjang pesisir barat Aceh. Oleh karena itu pemekaran provinsi itu penting dilakukan untuk mempercepat kemajuan daerah-daerah tertinggal di Provinsi NAD.

Ditambahkan pula oleh Azmir bahwa tujuan pemekaran provinsi baru adalah untuk percepatan pembangunan dan demi perbaikan masa depan masyarakat Aceh. Sebagai warga Aceh, saya selama ini merasakan adanya ketidakadilan pembangunan di provinsi ini. Dimana pembangunan di Aceh Selatan dan sejumlah daerah lainnya jauh tertinggal dibandingkan daerah pesisir utara Aceh Aceh dan kawasan timur.

\section{Usaha yang Dilakukan untuk Mewujudkan Provinsi ABAS}

Dalam usaha untuk mewujudkan ide pemekaran wilayah Aceh tersebut, ada beberapa upaya yang dilakukan untuk penggalangan dukungan dari berbagai pihak. Dalam hal ini, komite pemekaran ABAS yang diketuai oleh

15 Harian Analisa, 11 Pebruari 2008. 
Tjut Agam berusaha untuk mencari dukungan dari masyarakat setempat dengan cara mengumpulkan tanda tangan masyarakat di atas kain putih. Mereka berhasil mengumpulkan ribuan tanda tangan dari masyarakat yang mendiami daerah Aceh Barat dan Selatan. Selain itu mereka juga berusaha untuk mencari dukungan dari ulama-ulama setempat karena mereka beranggapan bahwa ulama-ulama setempat memiliki kekuatan moril sebagai kelompok pengarah masyarakat untuk melancarkan usaha pencapaian terbentuknya provinsi ABAS. Selanjutnya mereka telah berhasil mendapat dukungan dari Forum Komunikasi Kampung (FKK) yang terdapat di kabupaten-kabupaten yang ingin bergabung dalam provinsi ABAS. Usahausaha penggalangan dukungan tersebut merupakan salah satu tahapan dari tahapan-tahapan prosedur yang harus dilakukan dalam mengusulkan pemekaran provinsi baru.

Pembentukan provinsi ABAS juga mendapat dukungan dari Partai Nasional. Dalam hal ini Ketua umum Dewan Pimpinan Pusat Partai Demokrasi Indonesia Perjuangan (PDI-P) Megawati Soekanoputri memberikan dukungan penuh atas pembentukan provinsi ABAS sebagai pemekaran dari provinsi NAD dalam kerangka Negara Kesatuan Republik Indonesia (NKRI). Sebagai wujud dari dukungan pembentukan Provinsi ALA dan ABAS, Taruna Merah Putih yang rupakan sayap perjuangan resmi PDl-P menggelar diskusi yang bertema "Meneropong Masa Depan Aceh: Pembentukan ALA-ABAS sebagai Solusi dengan menampilakan Letjen Pumawirawan Kiki Syahnakri, Wakil Ketua Komisi II DPRRI Eka Santoso, Bupati Bener Meriah Tagore Abu Bakar, Ketua DPRK Aceh Tengah Syukur Kobath dan Ketua Komite Persiapan Pembentukan Provinsi (KP3) ABAS Tjut Agam sebagai pembicara di Kantor Pusat DPP PDI-P di Lentcng Agung, Jakarta Pusat. ${ }^{16}$

\section{Tantangan dalam Mewujudkan Provinsi ABAS}

Akan tetapi wacana dan usulan pembentukan provinsi ABAS di Aceh mendapat tantangan dari berbagai lapisan masyarakat, terutama gubernur NAD Irwandy Yusuf serta sebagian besar elit politik di pemerintah pusat Aceh. Dalam hal ini Irwandy Yusuf melalui surat No. 125/1996 tanggal 23

\footnotetext{
${ }^{16}$ Harian Berita Sore, 05 Juni 2008.
} 
Januari 2008 yang ditujukan kepada Ketua DPR-RI, Agung Laksono, menolak pemekaran Provinsi ABAS karena bertentangan dengan MoU Helsinki. ${ }^{17}$ Dalam $M o U$ Helsinki telah disebutkan dengan jelas tentang batasan kepada batas wilayah Aceh adalah merujuk kepada batas wilayah Aceh tahun 1956 yang daerahnya itu membentang dari Sabang sampai dengan wilayah tenggara dan timur Aceh yang berbatasan dengan wilayah Sumatera Utara. Wilayah Aceh tersebut dikenal dengan istilah "Aceh Lhee Sagoe". Selanjutnya lrwandy menambahkan, jika DPR RI tetap mengagendakan RUU Pemekaran ALA dan ABAS maka akan dapat mengganggu keamanan dan kedamaian yang sudah terwujud di Aceh sejak ditandatanganinya MoU Helsinki.

Ketua DPRA Said Fuad Zakaria, Wakil Gubernur NAD Muhammad Nazar, Sofyan Daud mantan komandan GAM, juga mengatakan hal yang senada. Mereka tidak menyetujui ide pemekaran tersebut karena kita sekarang sedang fokuskan untuk mengimplementasikan hasil perjanjian perdamaian MoU Helsinki. Dengan demikian para elit politik pemerintah pusat Aceh mengkhawatirkan pemekaran wilayah tersebut akan mengancam perdamaian yang sedang terwujud di daerah NAD.

Selain itu Tim Pemantau MoU Helsinki (MoU Helsinki Wach) juga menolak rencana pembahasan usul inisiatif DPR RI tentang RUU Pemekaran provinsi Baru ABAS. Di sisi lain menurut Koordinator Umum MoU Helsinki Watch, M. Nur Djuli, usulan pemekaran provinsi baru ini akan menimbulkan konflik horizontal antara masyarakat pro pemekaran dan kontra pemekaran.

Di samping itu Mukhlis Mukhtar, Ketua Komisi A DPRA dalam harian Jawa Pos mengatakan bahwa keterlambatan pembangunan ekonomi yang menjadi alasan kuat pemekaran di wilayah ini sebenamya tidak hanya terjadi di daerah pantai barat selatan saja, akan tetapi sesungguhnya juga terjadi juga di belahan bumi Aceh yang lain seperti pesisir timur Aceh maupun wilayah Aceh bahagian tengah dan tenggara. Hal ini terjadi bukan hanya terjadi pada periode pemerintahan yang baru-Irwandi dan Nazar-akan tetapi sudah terjadi pada periode-periode sebelumnya. ${ }^{18}$

17 Tabloid Berita Kontras, No. 422, Th. X, 31 Januari - 6 Pebruari 2008 dan baca juga harian Berita Sore, 06 Juni 2008.

18 Jawa Pos, 24 Oktober 2008. 
Dalam wawancara tersebut Mukhlis Mukhtar yang juga merupakan anggota dari Fraksi Reformasi, mengatakan keraguan beliau akan murninya ide pemekaran ini datang dari masyarakat. Alasan pemerataan ekonomi yang dikemukakan juga sepatutnya bukan hanya terjadi di pesisir barat selatan Aceh saja akan tetapi juga terjadi di pesisir timur Aceh juga. Hal ini bukan salah pemerintah pusat Aceh sekarang, akan tetapi ini merupakan warisan dari pemerintahan sebelumnya yang cenderung sentralistik. Oleh karena itu, yang sepatutnya bertanggung jawab akan masalah ini adalah penguasapenguasa yang memimpin daerah Aceh sebelum ini.

Oleh karena usulan pemekaran wilayah provinsi ABAS tidak mendapat dukungan dari DPRA, Gubernur dan Pemerintahan Daerah (Pemda) NAD maka para pencetus ide pembentukan Provinsi ABAS berusaha Jangsung mengusuJkan ke DPR RI. Usulan tersebut sudah sempat dimasukkan dalam agenda pembicaraan di DPR RI pada tahun 2004, tetapi usulan tersebut tidak sempat dibahas karena pergantian anggota DPR-RI yang telah habis masa jabatannya periode 1999-2004.

Kemudian usulan pembentukan Provinsi ABAS masuk kembali ke DPR RI melalui usul inisiatif yang dibahas dalam rapat Paripuma DPR RI pada hari Selasa, 22 Januari 2008. Pada saat itu anggota DPR RI Fraksi PBR (Partai Bintang Reformasi), Zainal Abidin Hussein menginterupsi rapat dan menyatakan sikap tidak setuju terhadap pembentukan Provinsi ABAS. Usulan pembentukan tersebut menurut beliau sudah kadaluwarsa karena diusulkan sebelum disahkannya UU Pemerintahan Aceh (UU-PA). Interupsi tersebut telah mementahkan kembali usulan pembentukan provinsi ABAS dan pimpinan rapat sidang Soetardjo Soerjogoeritno menyerahkan kembali pembahasan pemekaran Provinsi ABAS ke Komisi II DPR RI. ${ }^{19}$

Selanjutnya dalam rapat konsultasi pimpinan dan perwakilan fraksifraksi Komisi II DPR RI dengan Menteri Dalam Negeri RI Mardiyanto, Selasa (27/05/2008) malam, hanya menyepakati untuk membahas 12 calon daerah otonom kabupaten/ kota. Hal ini berarti calon provinsi ALA dan ABAS tidak memiliki peluang untuk dibahas pada tahun 2008. Menurut Nasir Djamil, di Komisi II DPR RI pada saat sekarang ini ada 50 RUU calon daerah otonom. Ada sejumlah 12 daerah yang telah mendapat Amanat Presiden (Ampres), 15

19 Tabloid Berita Kontras, No. 422, Th. X, 31 Januari -6 Pebruari 2008. 
daerah masih di meja Presiden dan selebihnya masih dalam proses penyelesaian di Komisi II DPR RI. Calon Provinsi ALA dan ABAS masuk dalam kategori yang masih dalam proses penyelesaian di Komisi II DPR RI.20

Dalam usaha menuntut pemekaran dari provinsi NAD, ratusan elemen masyarakat dari kabupaten/kota dari ALA dan ABAS, termasuk pimpinan dan anggota DPRK, melakukan demontrasi ke Jakarta. Kehadiran elemen masyarakat tersebut dimaksudkan untuk membantah isu yang selama ini tersebar bahwa keinginan untuk melakukan pemekaran tersebut merupakan kepentingan segelintir elite. Dalam demostrasi ini hadir kepala desa, aktivis LSM, pemuda, mahasiswa dan termasuk pula ulama. Dengan demikian tujuan dari demonstrasi ini adalah untuk membuktikan bahwa pemekaran tersebut merupakan aspirasi masyarakat yang tidak dibaca oleh para elite politik di Banda Aceh. $^{21}$

Di samping itu Forum Bersama Pimpinan/Anggota DPR Kabupaten/ kota se ALA dan ABAS mengeluarkan pemyataan sikap untuk tidak ikut serta dalam Pemilu 2009 jikalau aspirasi pemekaran itu tidak ditanggapi. Bersamaan dengan pernyataan sikap tersebur, DPRK wilayah Aceh Barat Selatan secara khusus meyertakan dokumen pembentukan provinsi ABAS. Dokumen tersebut ditandatangani oleh Pimpinan DPRK Aceh Barat, Aceh Selatan, Siemeulu, Nagan Raya, dan Aceh Barat Daya. Dokumen dukungan itu ditandatangani pada 29 Pebruari 2008 dangan No. Surat: 11/DPRK-u/ABAS/ 2008. Dukungan ini merupakan tindak lanjut dari dukungan sebelumnya yang dikeluarkan pada 22 Oktober 2003.22

Sementara itu, Gerakan Muda Pembaruan Susoh Aceh Barat Daya (GMPS) dan Forum Mahasiswa Pascasarjana Aceh Barat Daya (FoMPas), dalam siaran persnya kepada Serambi $(14 / 05 / 2008)$ menyatakan bahwa isu pemekaran yang digulirkan itu mulai menimbulkan keresahan dalam masyarakat. Mereka menambahkan pula bahwa aksi gabungan ALA-ABAS ini telah menggiring kondisi psikologi masyarakat yang sedang menikmati perdamaian ke arah konflik horizontal.

20 Serambi Indonesia, 29 Mei 2008.

21 Serambi Indonesia, 14 Mei 2008.

22 Serambi Indonesia, 15 Mei 2008. 


\section{G. Analisis terhadap Konflik Pembentukan Provinsi ABAS}

Berdasarkan deskripsi di atas, usulan mengenai pembentukan Provinsi ABAS yang merupakan pemekaran dari Provinsi NAD telah menimbulkan konflik. Konflik yang terjadi dapat dibagi dalam dua kelompok konflik yaitu, konflik horisontal antara masyarakat yang pro dan kontra terhadap usulan pembentukan Provinsi ABAS dan konflik vertikal antara kelompok yang pro pembentukan provinsi ABAS dengan Pemerintah NAD.

\section{Konflik Horisontal}

Usulan pembentukan Provinsi ABAS telah mendatangkan pro dan kontra di kalangan masyarakat ABAS sendiri. Sebagian masyarakat yang berada dalam wilayah ABAS mengkhawatirkan usulan tersebut akan dapat mengganggu kedamaian yang telah terwujud selama ini. Konclisi ini terjadi karena ide pemekaran wilayah tersebut tidak mum; berasal dari aspirasi masyarakat (grass root), tetapi lebih merupakan aspirasi dari elit politik ABAS. Hal ini tampak dalam upaya penggalangan dukungan yang dilakukan oleh komite persiapan pcmbentukan Provinsi ABAS dalam mengumpulkan tanda tangan dari masyarakat dan upaya mereka mencari dukungan dari kalangan ulama.

\section{Konflik Vertikal}

Konflik vertikal ini terjadi antara kelompok yang pro pembentukan Provinsi ABAS (KP3 ABAS) dengan pemerintah Nanggro Aceh Darussalam (NAD). Berdasarkan aturan yang telah ditetapkan tentang prosedur pengusulan pemekaran wilayah adalah, setelah usulan tersebut mendapat dukungan dari DPRK setempat maka usulan tersebut harus mendapat persetujuan dari pemerintah NAD dan DPRA. Akan tetapi usulan pembentukan provinsi ABAS tidak mendapatkan dukungan dari pemerintah NAD dan DPRA, sehingga mereka berusaha untuk mengusulkan secara langsung usulan tersebut ke DPR RI. Hubungan antara berbagai pihak yang terlibat dalam konflik pembentukan Provinsi ABAS dapat dipetakan dalam skema berikut: 


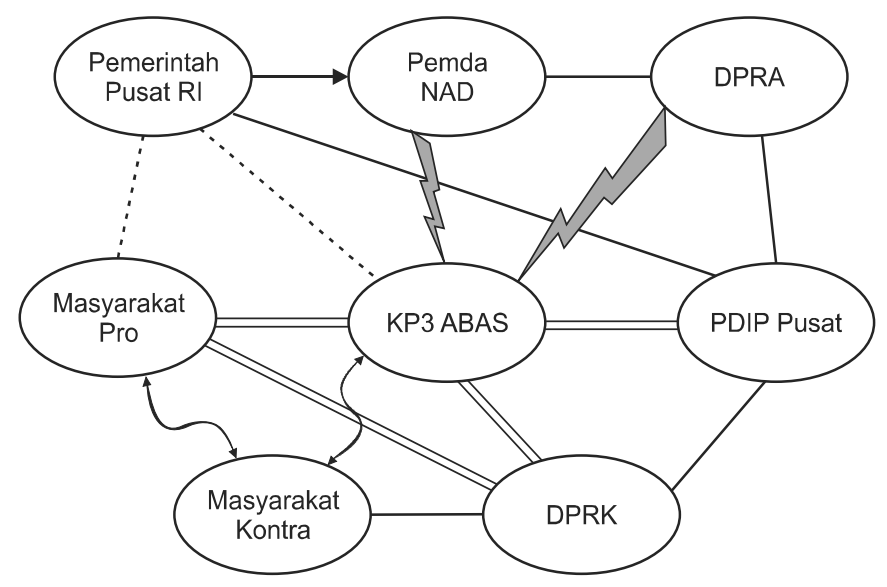

Keterangan Simbol:

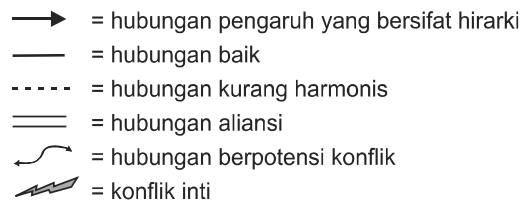

Berdasarkan teori pendekatan konflik maka konflik yang timbul dalam upaya pembentukan Provinsi ABAS dapat didekati dengan teori kebutuhan manusia. Dimana teori ini mengasumsikan bahwa konflik yang berakar dalam masyarakat disebabkan oleh kebutuhan dasar manusia baik itu fisik, psikis, maupun sosial yang tidak terpenuhi atau dikecewakan. Sebagaimana yang telah dipaparkan sebelumnya bahwa kabupaten yang bergabung untuk membentuk satu Provinsi ABAS adalah merupakan kabupaten yang mengalami keterlambatan dalam pembangunan. Dengan kata lain daerah-daerah tersebut merupakan daerah yang termarginalkan dalam proses pembangunan Aceh selama ini. Sehingga tujuan mereka membentuk provinsi ABAS adalah untuk mempercepat pembangunan dan memangkas birokrasi yang selama ini cenderung berbelit-belit serta memperpendek rentang kendali dalam melayani masyarakat.

Pada hakikatnya konflik ini bisa diselesaikan membentuk provinsi baru karena pembentukan provinsi baru juga akan menimbulkan ketegangan dan 
konflik pada berbagai pihak yang terkait. Oleh karena itu untuk menyelesaikan konflik tersebut, ada dua tahapan yang perlu dilakukan, yaitu:

a. Membantu pihak-pihak yang berkonflik untuk mengidentifikasi dan menyampaikan kebutuhan yang tidak terpenuhi dan memunculkan berbagai pilihan untuk memenuhi kebutuhan tersebut.

b. Bagi pihak-pihak tersebut agar mencapai kesepakatan tentang kebutuhan identitas penting dari semua pihak.

Selain itu konflik pemekaran provinsi ini juga dapat didekati dengan teori transformasi konflik. Dimana teori ini mengasumsikan bahwa konflik tersebut muncul disebabkan oleh persoalan yang betul-betul riil, berupa ketidaksetaraan dan ketidakadilan yang ditunjukkan oleh kerangka kerja sosial, budaya dan ekonomi yang saling bersaingan. Adapun sasaran kerja yang didasarkan pada teori transformasi konflik adalah:

a. Mengubah struktur dan kerangka kerja yang menyebabkan ketidaksetaraan dan ketidakadilan termasuk redistribusi ekonomi.

b. Memperbaiki hubungan jangka panjang dan sikap di antara pihak-pihak yang terlibat konflik.

c. Mengembangkan proses dan sistem yang mendukung pemberdayaan keadilan, perdamaian, maaf, rekonsiliasi dan pengakuan.

Di samping itu konf1ik pemekaran wilayah ini juga telah menimbulkan perbedaan persepsi di kalangan elit politik Aceh. Sebagian besar elit politik pusat Aceh mengkhawatirkan pemekaran wilayah Aceh akan mempengaruhi identitas Aceh itu sendiri dan juga akan mengancam keberlangsungan perjanjian damai MoU Helsinki. Oleh karena selama ini daerah Aceh lebih dikenal dengan istilah "Aceh Lhee Sagoe". Jikalau usulan pembentukan Provinsi ABAS disetujui maka identitas "Aceh Lhee Sagoe" akan hilang. Wilayah Aceh yang sebelumnya berbentuk segi tiga akan berubah bentuknya seiring dengan disahkannya provinsi ABAS. Dengan kata lain konflik itu timbul karena disebabkan oleh perasaan akan adanya identitas yang terancam. Sasaran kerja yang didasarkan pada teori identitas adalah:

a. Workshop dan dialog yang difasilitasi bagi pihak-pihak yang berkonflik untuk tujuan mengidentifikasi ancaman dan ketakutan yang mereka rasakan serta untuk membangun empati dan rekonsiliasi di antara mereka. 
b. Bersama-sama mencapai kesepakatan mengenai kebutuhan identitas semua pihak.

Sebagaimana yang dikemukakan oleh Ryaas Rasyid bahwa pemekaran suatu wilayah kerap menimbulkan konflik karena mengubah peta sosiologis dan dapat memungkinkan adanya kelompok-kelompok yang tadinya minoritas menjadi mayoritas atau sebaliknya. ${ }^{23}$

Dengan maraknya pemekaran wilayah, partai politik adalah pihak yang paling diuntungkan, sebab calon-calonnya di DPRD (DPRK) yang dalam pemilu lalu tidak masuk, akan bisa masuk lagi setelah dibuat pemekaran. Selain itu, para birokrat juga akan mengambil keuntungan, dimana mereka yang selama ini tidak memiliki jabatan akan mendapatjabatan baru.

Demikian juga halnya dengan para pemasok barang dan konsultan konstruksi juga ikut mendapatkan untung, mulai dari pengadaan komputer, beli kendaraan baru sampai pembangunan gedung. Ketiga pilar yaitu, partai politik, birokrat dan pemasok barang itulah yang selalu mendukung pemekaran dan rakyat tidak pernah atau sangat sedikit yang mendapatkan keuntungan dari adanya pemekaran wilayah.

Di samping itu pakar otonomi daerah, Ryaas Rasyid, dalam harian Suara Karya (14/12/2007) mengatakan bahwa keinginan sejumlah daerah untuk melakukan pemekaran akan membuat negara Indonesia bangkrut. Sebab anggaran biaya operasional pemeriniah akan semakin meningkat, sementara alokasi anggaran untuk rakyat semakin sedikit. Di samping itu, pemekaran juga akan menyunpan potensi konflik.

Dengan demikian tujuan utama pemekaran suatu daerah sesungguhnya adalah untuk meningkatkan kesejahteraan masyarakat melalui peningkatan pelayanan, percepatan pertumbuhan kehidupan demokrasi, percepatan pelaksanaan pembangunan ekonomi daerah, peningkatan pengelolaan potensi daerah, peningkatan keamanan dan ketertiban serta peningkatan hubungan antara pusat dengan daerah. Namun pemekaran juga harus dijaga supaya tidak membuat daerah hasil pemekaran mengalami kesulitan dan menimbulkan masalah baru. Jangan sampai jadi beban bagi pemerintah pusat karena tidak mampu melaksanakan otonomi daerahnya.

${ }^{23}$ Suara Karya, 14 Desernber 2007. 
Kalaupun pemerintah pusat memberikan dana perimbangan kepada provinsi hasil pemekaran, dana tersebut tidak cukup untuk membiayai perekonomian dan pembangunan hingga lima tahun setelah provinsi tersebut dibentuk. Provinsi baru itu akan sulit membangun karena alokasi dana otomatis akan diprioritaskan untuk membangun infrastruktur birokrasi daerah, gaji pegawai, pembangunan kantor gubernur, kantor DPRD, rumah dinas Gubernur, wakil gubernur dan ketua DPRD serta pengadaan kendaraan dinas untuk para pejabat. Kondisi ini justru akan memperlambat kemajuan pembangunan di wilayah pesisir barat selatan Aceh.

Oleh karena itu untuk menghindari munculnya konflik yang berhubungan dengan pemekaran wilayah maka pendekatan kesejahteraan merupakan salah satu pendekatan untuk meredam konflik tersebut. Karena kemiskinan dan kemarginalan merupakan salah satu pemicu munculnya konflik di kalangan masyarakat.

Dengan demikian Pemerintah NAD harus memprioritaskan program pembangunan pada daerah-daerah yang selama ini telah mengalami keterlambatan dan ketertinggalan dalam modemisasi dalam berbagai aspek kehidupan. Selain itu pemerintah NAD juga harus memangkas birokrasi yang selama ini turut andil dalam memperlambat pembangunan di daerah-daerah terpencil. Di samping itu. pemerintah NAD harus memberikan otonomi yang seluas-luasnya kepada masing-masing kabupaten/kota untuk mengurus masalahnya sendiri.

\section{H. Kesimpulan}

Berdasarkan deskripsi di atas, dapat ditarik suatu kesimpulan bahwa ide pemekaran wilayah dalam provinsi NAD itu timbul karena adanya ketidakadilan dan kesenjangan dalam pembangunan di Aceh. Sehingga ada beberapa kabupaten yang termarginalkan dari pembangunan. Hal ini telah mendorong sebagian elit politik setempat untuk membentuk provinsi baru dalam rangka mempercepat pembangunan dan memperpendek rentang kendali dalam melayani masyarakat, Aspirasi ini muncul dari kalangan atas (top down) sehingga telah memunculkan konflik, baik itu konflik horizontal maupun konflik vertikal. 
Meskipun tujuan pemekaran suatu daerah sesungguhnya adalah untuk meningkatkan kesejahteraan masyarakat melalui peningkatan pelayanan, percepatan pertumbuhan kehidupan demokrasi, percepatan pelaksanaan pembangunan ekonomi daerah, peningkatan pengelolaan potensi daerah, peningkatan keamanan dan ketertiban serta peningkatan hubungan antara pusat dengan daerah. Namun pemekaran juga akan mengalami kesulitan dan menimbulkan masalah baru. Masalah baru akan timbul karena dana perimbangan kepada provinsi hasil pemekaran, tidak cukup untuk membiayai perekonomian dan pembangunan hingga lima tahun setelah provinsi tersebut dibentuk Provinsi baru itu akan sulit membangun karena alokasi akan diprioritaskan untuk membangun infrastruktur birokrasi gaji pegawai, pembangunan Kantor gubernur, Kantor DPRD. rumah dinas Gubernur, wakil gubernur.

Dengan demikian usulan pembentukan provinsi baru yang bertujuan untuk mempercepat pembangunan dan meningkatkan kesejahteraan masyarakat justru akan memberikan keuntungan pada segelintir kelompok masyarakat bukan pada seluruh masyarakat. Dengan kata lain hanya partai politik, birokrat dan pemasok barang yang akan mendapatkan keuntungan serta selalu mendukung pemekaran sedangkan rakyat tidak pernah atau sangat sedikit yang mendapatkan keuntungan dari adanya pemekaran wilayah.

Oleh karena itu untuk menyelesaikan konflik tentang pemekaran wilayah dalam provinsi NAD maka Pemerintah NAD berkewajiban untuk menjadikan program pembangunan di kabupaten-kabupaten yang tertinggal itu sebagai skala prioritas yang utama. Pendekatan kesejahteraan itu merupakan salah satu eara untuk mengurangi timbulnya konflik di dalam masyarakat Aceh.[w] 


\section{BIBLIOGRAFI}

Folger, J.P. and Poole, M.S., Working Through Conflict, Montreal: Longman, 2001 .

James P. Spradley, Metode Etnografi, Terj. Misbah Zulfa Elizabeth, Yogyakarta: Tiara Wacana, 2006.

M. Mukhsin Jamil, (ed.), Mengelola Konflik Membangun Damai, Semarang: WMC IAIN Walisongo, 2007.

Ucu Martanto, "Kemiskinan di Indonesia: Potret Buram Desentralisasi," dalam Joumal Mandatory, Jogjakarta: IRE, 2007.

Undang-Undang Republik Indonesia Nomor 32 Tahun 2004

\section{Surat Kabar dan Tabloid:}

Analisa, 11 Pebruari 2008

Berita Sore, 05 dan 06 Juni 2008.

Jawa Pos, 24 Oktober 2008

Serambi Indonesia, 14 dan 15 Mei 2008

Suara Karya, 14 Desember 2007

Tabloid Kontras, No. 422, Th. X, 31 Januari - 6 Pebruari 2008. 